\title{
Drugs merger seeks strength in breadth
}

[LONDON] A single pharmaceutical company combining a unique breadth and depth of expertise in chemistry, biology and genomics appears likely to emerge from the merger currently under discussion between the two British-based companies Glaxo Wellcome and SmithKline Beecham.

Such a multidisciplinary approach to the search for new drugs fits in well with the previous research strategies of both companies. One traditional route to drug discovery involves choosing a 'target' disorder where a drug will be of benefit, and then experimenting with chemicals until a combination is found that will treat the target safely. This method has seen successes, such as Glaxo's anti-ulcer treatment Zantac. But there have been many more failures.

Glaxo now believes that this is too much of a 'hit or miss' approach. Under the direction of its chief executive and former director of research, Sir Richard Sykes, the company has sought to inject strategic thinking into selecting targets, finding appropriate drugs for those targets, and then using appropriate tools and skills to develop and market the drugs (see Nature 367, 402; 1994).

In terms of science, this has meant using cell biology, physiology and pharmacology as a guide to the cause of a disease. It means using genetics through assembling databases of patients to find genes involved in disease. And it means using combinatorial chemistry to assemble the most appropriate drug.

Combinatorial chemistry is among Glaxo Wellcome's strengths, particularly after its \$533 million purchase of the US company Affymax (see Nature 372, 373; 1995). Wellcome was well known for its work supporting basic biology, which the merged company continues to maintain. And SmithKline Beecham was among the first companies to invest substantially in genomics and bioinformatics.

Tim Harris, senior vice-president of research at Axys Pharmaceuticals in California and Glaxo Wellcome's former director of biotechnology, thinks that a merger between Glaxo Wellcome and SmithKline Beecham has strong potential, on the basis of "the combination of Glaxo Wellcome's screening technology and SmithKline's genomics expertise which most other companies do not have".

Not everyone appears convinced that the new strategy will work. One delegate at a Glaxo Wellcome research seminar at the end of last year said that a sharper focus on targets and on drug design would reduce the number of early drugs failures. But he warned that the new strategy could prove costly if the company begins to lose more drugs at later - more expensive - stages of the develop-ment process.

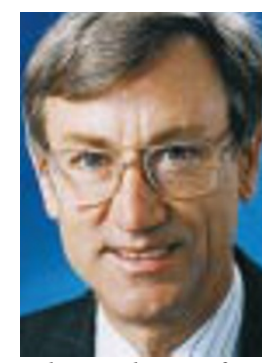

Sykes: architect of broad-base strategy.
Jim Niedel, director of worldwide research and development at Glaxo Wellcome, said at the seminar that it was too early to judge whether the strategy is working as it had begun operating only in 1996. But he said there were several encouraging signs.

Glaxo Wellcome had introduced 28 drugs for development in the past two years, he said, of which 80 per cent were still in the pipeline. "This is better than the industry average.

"I am not claiming that we are now targeting an 80 per cent success rate; but if you remember the old success rate was 10 per cent, and we are trying to reach a 20 per cent success rate, or even 25 per cent. We are on the way to doing that."

Pharmaceutical industry estimates suggest it can cost up to $\$ 350$ million and take 10 years to bring a single drug to market. The failure rate is high. Of every 100 drugs that go into development, only ten achieve registration, and only three generate significant amounts of money.

Niedel warned that the industry would "go out of business" unless the success rate for drugs that make significant profits was increased from 3 per cent to around 10 per cent. "We will never be 100 per cent; we will probably never be 50 per cent, but God love us if we cannot get the 10 per cent," he said.

Meanwhile, SmithKline has been making frequent public declaration of its confidence in its therapeutic strengths. A spokesman adds that knowledge about gene sequences and other aspects of 'genomics' is the key to future drug design.

The company struck a groundbreaking \$125-million deal with Human Genome Sciences in 1993 (see box), and subsequently appointed Peter Goodfellow — then professor of genetics at the University of Cambridge — as head of genetics research. EhsanMasood

\section{Curtain falls on gene sequencing deal}

[PARIS] SmithKline Beecham, which reached a \$125-million agreement in 1993 with the gene sequencing company Human Genome Sciences (HGS), has suspended its use of that company's gene sequence database. The pharmaceutical company claims it has already exhaustively milked the database, and that other high-quality sequence data are increasingly available in the public domain.

SmithKline Beecham (SB), which is engaged in merger talks with Glaxo Wellcome (see above), has already identified more than 3,000 genes from the HGS database, according to Alain Archer, an SB spokesman. He points out that SB also recouped much of its original investment in a $\$ 140$ million deal agreed in 1996 that opened up HGS databases to Schering-Plough,

Synthelabo and Takeda Industries. "SB felt that it needed to [pause] and study the targets we have already identified, rather than just searching for more," he says. Also, says Archer, the increasing volume of gene sequence data available in the public domain means that the debate has changed since SB signed its original agreement with HGS in 1993. In particular, this has rendered increasingly unacceptable the stringent terms imposed by HGS at the time, such as the right to royalties on products developed from sequences, and a requirement that researchers wishing to gain access to the database should give HGS an exclusive option on patents resulting from their research.

The restrictions imposed by HGS resulted in a vigorous debate about whether the human genome should be mapped in the private or public domain (see Nature 371, 365; 1994).

John Sulston, director of Britain's Sanger Centre, argues that this debate is now going in the direction of those who wish to see the venture being primarily public-domain. "The public databases are being refined and added to by researchers all over the world, and are of very high quality; it is inevitable that the public domain will win under these circumstances because it becomes a much richer resource, and that is what we are now seeing."

The public-versus-private dispute "is now water under the bridge", says Richard Blevin, head of bioinformatics at Merck Sharpe and Dohme - a company that has backed public domain sequencing. Blevin argues that gaining access to sequence data is "no longer the issue" that it was a few years ago and that companies are focusing their efforts on the more difficult issue of the targets.

HGS itself has become a less prominent player in the sequencing business, following the split last year with its non-profitmaking partner, the Rockville-based Institute for Genomic Research, which has since made its sequence databases publicly available. Gene sequences are now a minor part of HGS's business, the company having focused on genomebased drugs. Declan Butler 